\title{
Between mountain and plain: new evidence for the Middle Palaeolithic in the northern Susiana Plain, Khuzestan, Iran
}

\author{
Saeid Bahramiyan ${ }^{1} \&$ Loghman Ahmadzadeh Shouhani ${ }^{2}$
}

The Middle East generally (Bar-Yosef 1994) and Iran specifically (Vahdati Nasab et al. 2013) have become a focus for the study of human migration between South-west Asia and Central and Eastern Asia during the Pleistocene (Asgari Khaneghah et al. 2005; Biglari \& Shidrang 2006; Heydari Guran 2012). In Iran, studies of the Palaeolithic have concentrated on the Zagros and Alborz areas, but recent work in the sub-montane areas, desert margins and lowland plains have also revealed interesting results regarding the activities of huntergatherer societies (Biglari et al. 2000; Dashtizadeh 2009; Vahdati Nasab et al. 2009, 2010, 2013; Darabi et al. 2012).

A survey was conducted in 2012, directed by Loqhman Ahmadzadeh Shouhani, along the western side of the Karkheh River in the north of the province of Khuzestan, south-west Iran. A total of 72 archaeological sites were identified. One of thesethe site of Khervali located in the Khervali Valley, $950 \mathrm{~m}$ to the west of the Karkheh Dam (Figures 1 \& 2) —was dated to the Paleolithic and subject to further systematic investigation.

Khervali, extending across an area of approximately $630 \times 2320 \mathrm{~m}^{2}$, is located at $130-160 \mathrm{~m}$ asl in an open valley in the foothills to the north of Susa (the northern part of the Susiana Plain). The surface of the site is relatively flat, sloping slightly north-west to south-east. The raised elevation of the site compared to the surrounding plain has protected it from the Holocene sedimentation process experienced below. The site lies directly on the Bakhtyari Conglomerate Formation (Figure 3), and is littered with rounded pieces of sandstone and an abundance of chert. A seasonal river flows through the Khervali Valley joining the Karkheh River. Unfortunately, the site has suffered extensive damage as a result of the construction of an asphalt access road for the Karkheh Dam.

University of Tehran, Enqelab Street, Tehran, Iran (Email: bahramiyan.saeid@gmail.com)

2 Department of Archaeology, Islamic Azad University, Tehran Centre Branch, Damavand Street, Tehran, Iran (Email: loghman_susa@yahoo.com) 


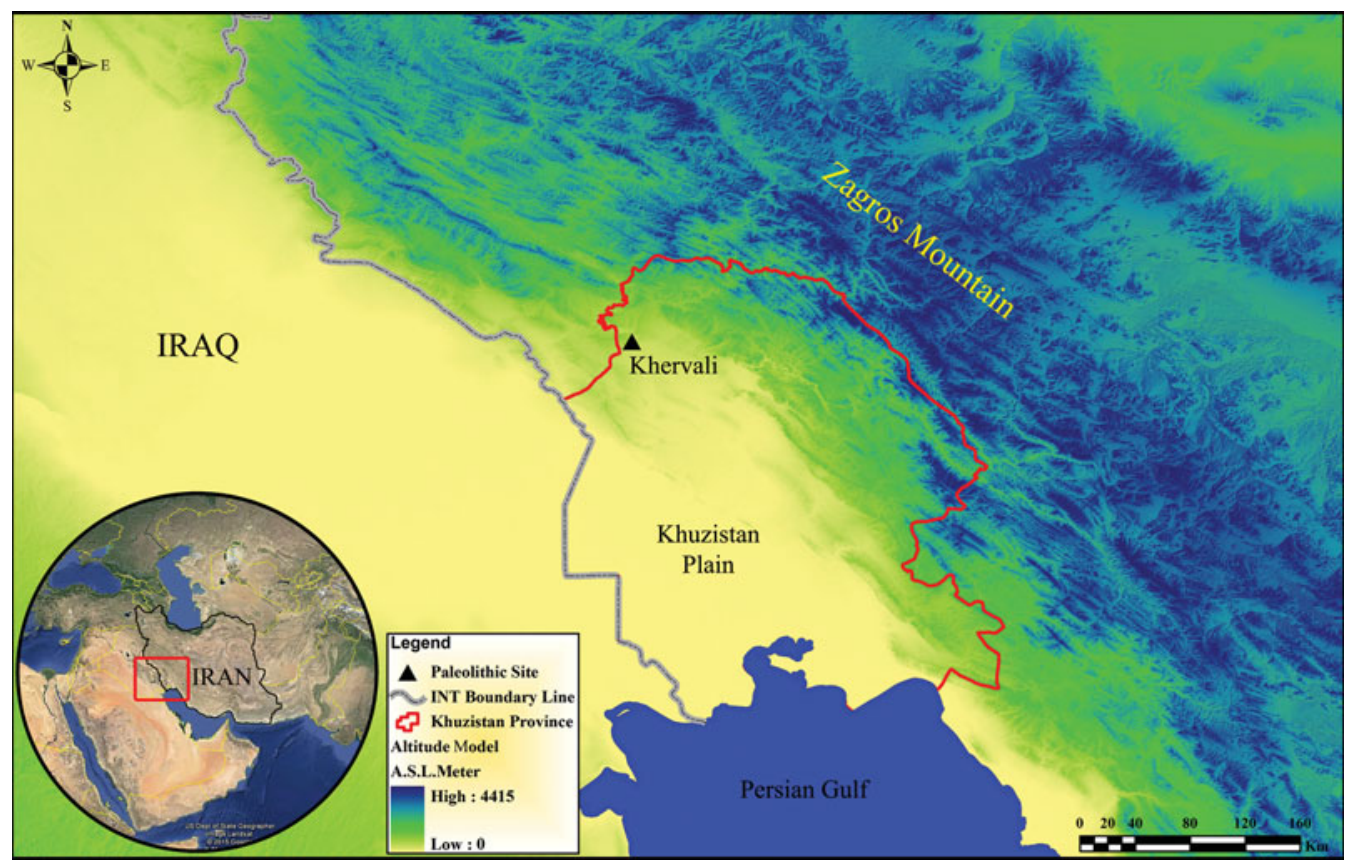

Figure 1. Geographic location map of Khervali Valley.

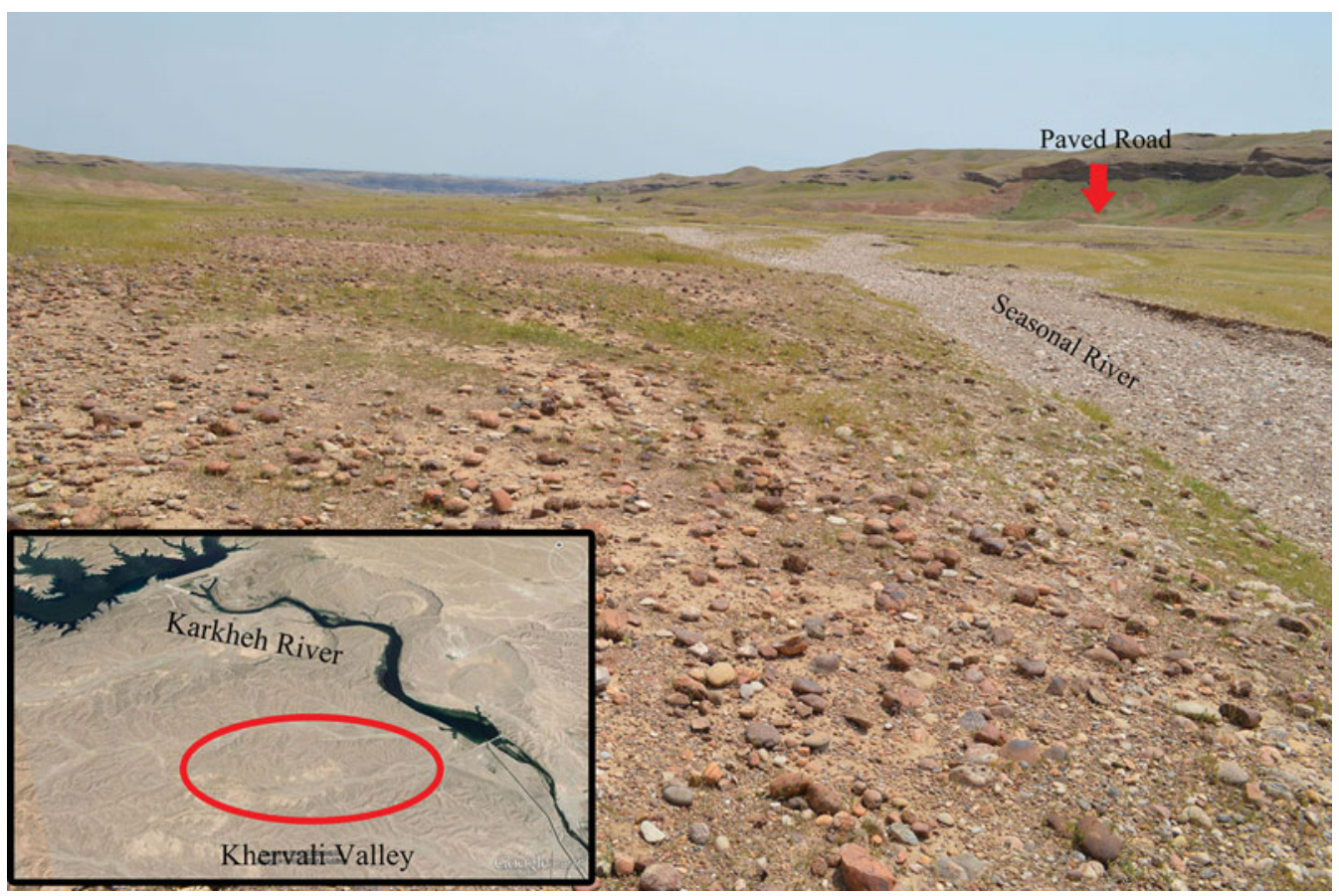

Figure 2. Location of Khervali Valley near Karkheh River (left bottom), and a view of the middle part of the Khervali Valley (conglomerate landscape).

C) Antiquity Publications Ltd, 2016 


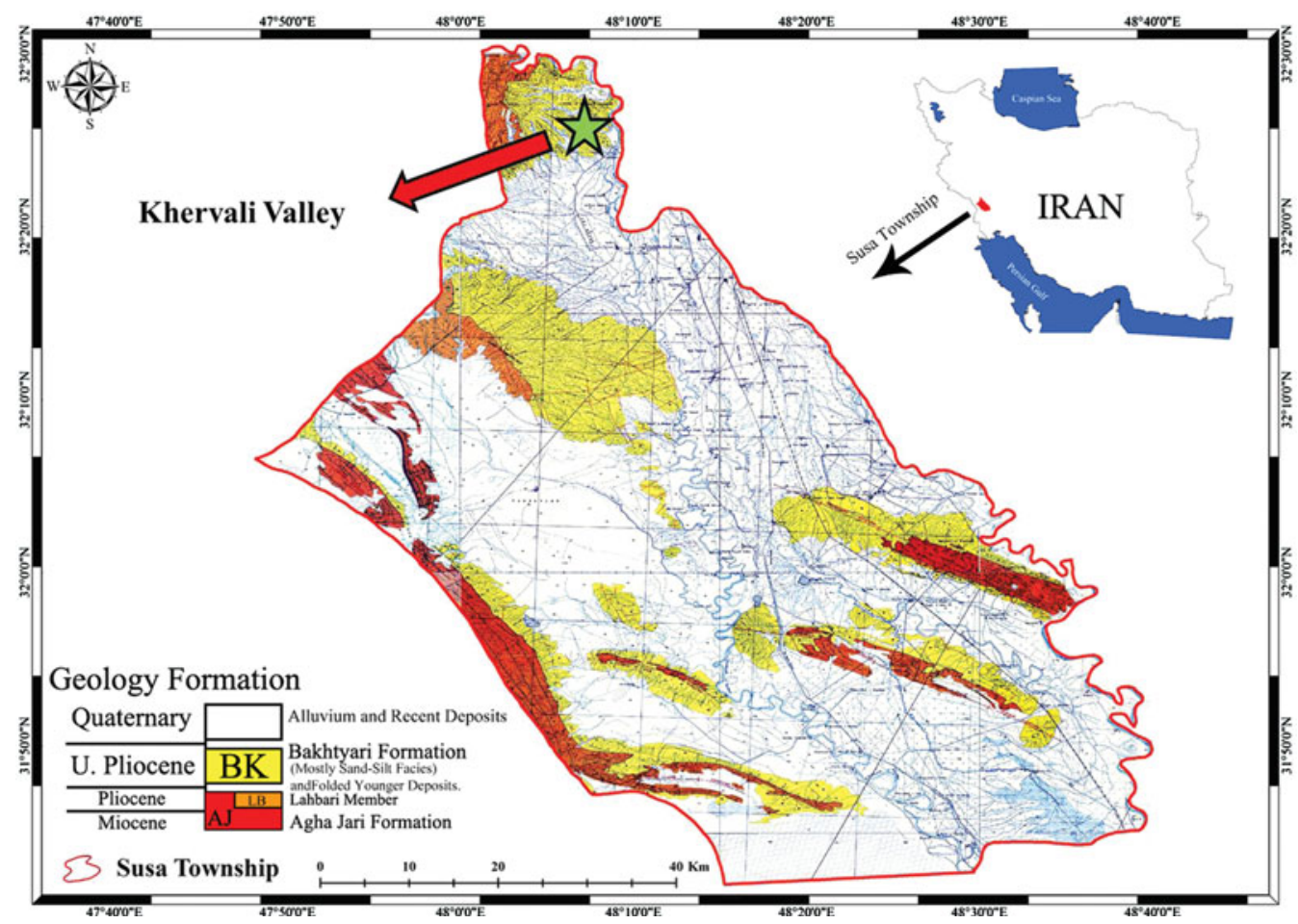

Figure 3. Geological map of Susa township; the yellow part is the Bakhtyari Formation (BK: conglomerate).

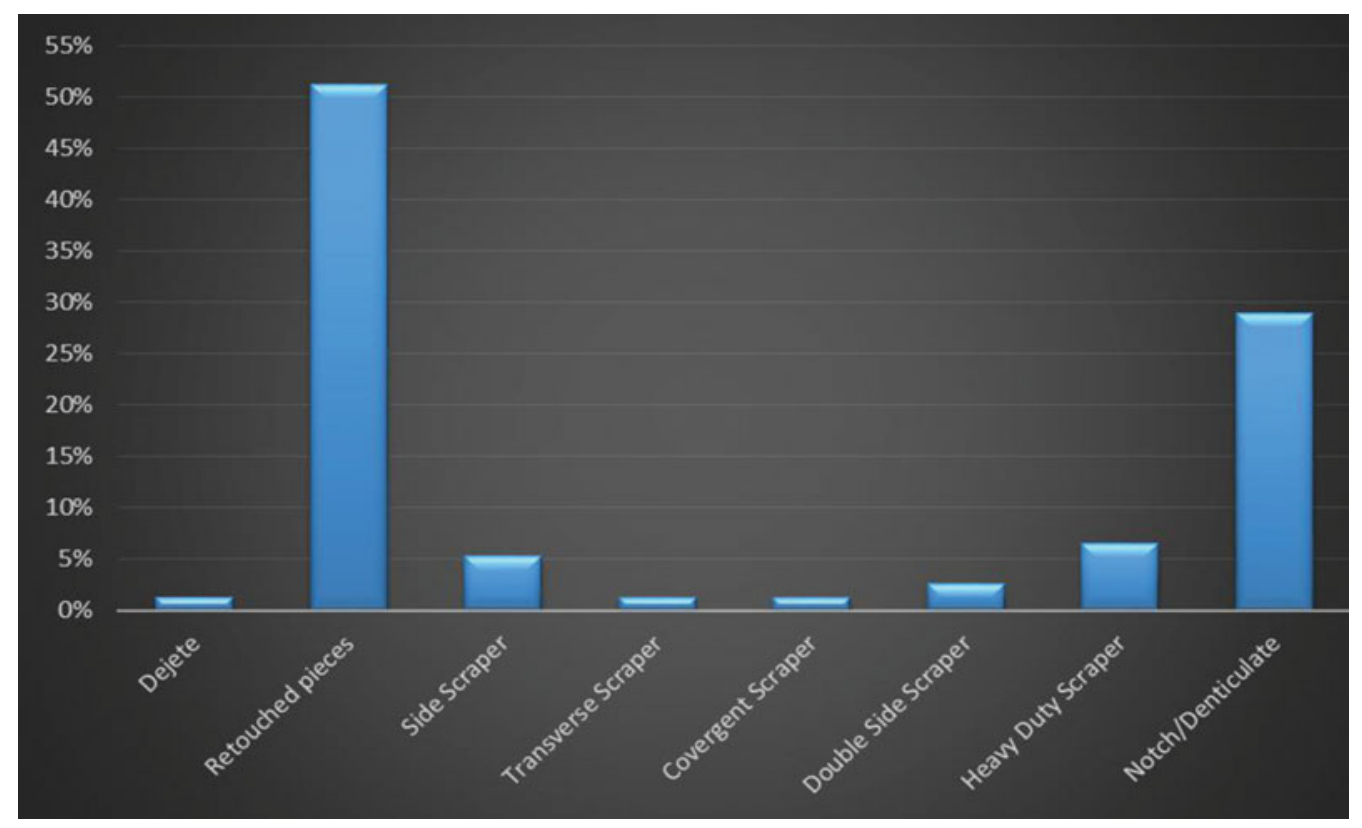

Figure 4. Abundance of the Khervali tools.

(C) Antiquity Publications Ltd, 2016 


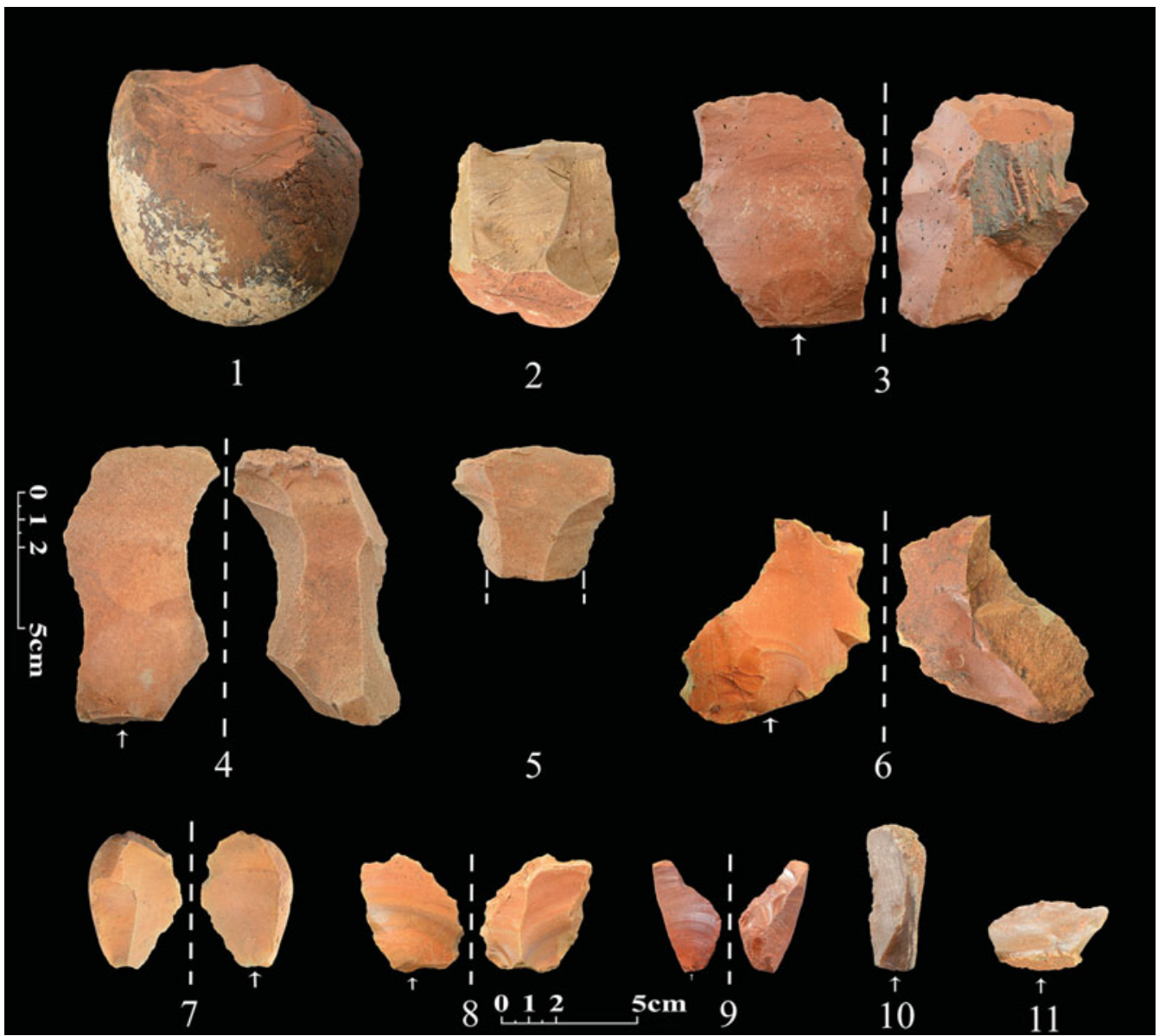

Figure 5. Some of the collected artefacts from the Khervali site: 1) corelchopper; 2) flake core 3) heavy duty scraper; 4-5) levallois flake; 6-7) denticulate flake; 8) scraper with heavy retouch; 9) dejete; 10) single-sided scraper; 11) transverse scraper.

Systematic survey of the Khervali site, including four circular concentrations with diameters of $20 \mathrm{~m}$, recovered 330 stone tools such as cores, core fragments and blank debitage. The cores can be categorised into three main groups: flakes (93.4\%), blades $(3.3 \%)$ and bladelets $(3.3 \%)$, which are reduced in an irregular and unidirectional way. Seventy-two tools, $23 \%$ of the total, include retouched pieces, notch-denticulate pieces, scrapers such as a dejete, a single-sided scraper, a heavy duty scraper and a transverse scraper (Figure $4 \& 5$ ). Of the tools, those made of flakes, a total of 73 pieces, are the most frequent (96\%); two tools are made of blades (2.6\%), and a single tool is made of a bladelet $(1.3 \%)$. Among the 73 pieces of debitage, $97.3 \%$ were separated from the core by flaking, and $2.7 \%$ by blading techniques. Given the frequency of flaking (Figure 6), the variety of scrapers and notch-denticulate tools, and the use of the Levallois technique, a Middle Palaeolithic date for the site is probable.

The tools used the raw materials available in the Khervali Valley, including flint, chert, jasper, opal, and occasionally sandstone and quartz. Most of the tools are made of (C) Antiquity Publications Ltd, 2016 


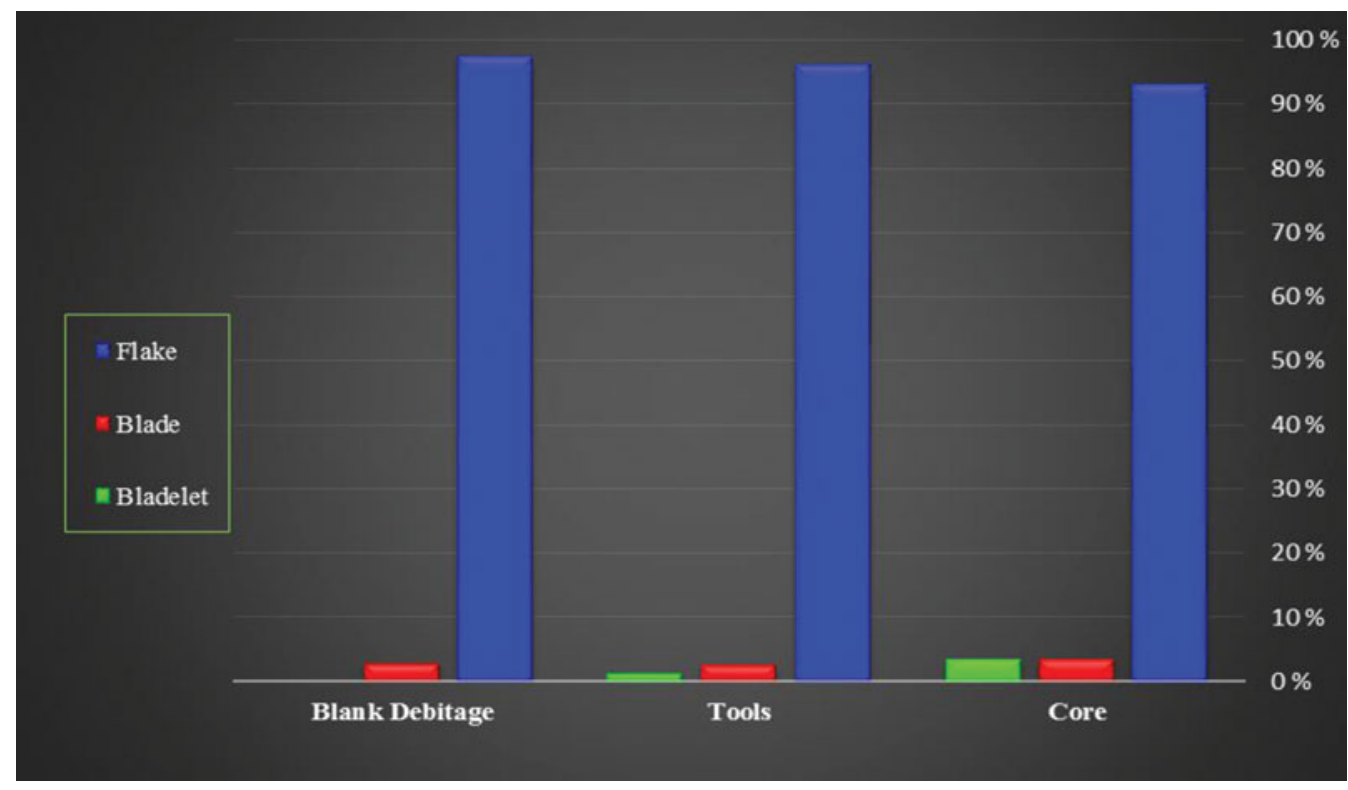

Figure 6. Chart of blank technology.

light-brown or crimson flint, and, in some cases, even appear in green and red, grey or cream flint. This raw material is the principal characteristic of the Bakhtyari Conglomerate Formation (Darvishzadeh 1991) on which the site was clearly and carefully located.

The discovery of the site at Khervali provides a rare example of a Palaeolithic site located between the Zagros Mountains and the lowlands of the Khuzestan Plain. Further study of this site will contribute to an understanding of not only the occupation of these regions during the Palaeolithic, but also to the broader study of the migration of humans into Central and Eastern Asia during the Pleistocene.

\section{Acknowledgements}

We thank Hamed Vahdati Nasab, Department of Archaeology, Tarbiat Modares University, and Sajjad Alibaigi, Department of Archaeology, Razi University, for commenting on this article.

\section{References}

Asgari Khaneghah, A., G. Berillon, J.J. Bahain, V. Zeitoun \& B. Chevrier. 2005. Jameiat-e pish az tarikh-e Iran: natayej-e moghadamati pazhouheshhay-e dirian ensan shenasi dar mantaghae-e Yazd, Damavand va Amoul. Bastanshenasi 4: 12-25 (in Persian).

Bar-Yosef, O. 1994. The Lower Paleolithic in the Near East. Journal of World Prehistory 8: 211-65. http://dx.doi.org/10.1007/BF02221050
Biglari, F. \& S. Shidrang. 2006. The Lower Paleolithic occupation of Iran. Near Eastern Archaeology 69: 160-68.

Biglari, F., G. NoKANDEH \& S. Heydari Guran. 2000. A recent find of a possible Lower Paleolithic assemblage from the foothills of the Zagros Mountains. Antiquity 74: 749-50.

Darabi, H., A. Javanmardzadeh, A. BeshKani $\&$ M. JAMI-AlAHMADI. 2012. Paleolithic occupation of the Mehran Plain in south-western Iran. Documenta Prehistorica XXXIX: 443-51. http://dx.doi.org/10.4312/dp.39.32

(C) Antiquity Publications Ltd, 2016 
DarVishzadeh, A. 1991. Geology of Iran. Tehran: Danesh-e Emruz (in Persian).

Dashtizadeh, A. 2009. Paleolithic remains from the north coast of the Persian Gulf: preliminary results from the Jam-o-Riz Plain, Bushehr Province, Iran. Antiquity Project Gallery 83(319). Available at: http://www.antiquity.ac.uk/projgall/ dashtizadeh319/ (accessed 28 July 2016).

Heydari Guran, S. 2012. The Corridor of Iran; early modern human dispersal into the Iranian Plateau: a geographical perspective, in H. Fahimi \& K. Alizadeh (ed.) Namvarnameh: 39-58. Tehran: Iran Negar (in Persian).

Vahdati Nasab, H., H. Mollasalehi, M. Saeedpour \& J. JAMSHIDI. 2009. Paleolithic Levalloisian assemblages from Boeen Zahra in the Qazvin Plain, Iran. Antiquity 83(320) Project Gallery. Available at: http://www.antiquity.ac.uk/projgall/nasab1/ (accessed 28 July 2016).
Vahdati Nasab, H., K. Roustaei \& H. RezVani. 2010. Delazian (Mirak I): evidence of Paleolithic settlement at the northern edge of the Iranian Central Desert, in P. Matthiae, F. Pinnock, L. Nigro $\&$ N. Marchetti (ed.) Proceedings of the $\sigma^{\text {th }}$ Archaeology of the Ancient Near East 2. Roma: Università di Roma 'La Sapienza'.

Vahdati Nasab, H., G.A. Clark \& S. Torkamandi. 2013. Late Pleistocene dispersal corridors across the Iranian Plateau: a case study from Mirak, a Middle Paleolithic site on the northern edge of the Iranian Central Desert (Dasht-e Kavir). Quaternary International 300: 267-81.

http://dx.doi.org/10.1016/j.quaint.2012.11.028 